\title{
THE FRIARS OF THE SACK IN BARCELONA: FINANCIAL AND PASTORAL PROFILE
}

\author{
ROBERT I. BURNS, S.J. \\ U.C.L.A. (U.S.A.)
}

From time to time an international movement of impressive scope will fall off the historians' map, like a carrack sailing past the edge of a flat earth, leaving only a faint and diminishing wake. The Friars of the Sack are one such phenomenon. Organizing suddenly over Provence in the mid-thirteenth century, they multiplied priories like Fibonacci's rabbits. From England to Palestine, and from Germany to the Spanish-Muslim frontier, over a hundred houses sprang up within a quarter century. They were popular for their ideology of poverty and care for the poor; but they also conducted programs of study at the universities of Bologna, Cambridge, Cologne, Oxford, Paris, Toulouse, and other intellectual centers. Then they disappeared. Suppressed by the ecumenical council of Lyons in 1274, as part of a policy to prune and control the wider Mendicant movement, these "Brothers of Penitence of Jesus Christ" have left behind no archives, histories, hagiographies, chartularies, or (unlike surviving Mendicant orders) institutes to promulgate their past ${ }^{1}$.

\footnotetext{
'See my Athenulfi (Attanulfi) Raimondo in the "Dizionario degli istituti di perfezione", ed. Guerrino PELlicCia and Giancarlo RocCA, 8 vols. to date (Rome, Edizioni Paoline, 1974-), I, pp. 960-961, and my extensive Penitenza di Gesù Cristo, Frati della, VI, 1398-1403. My previous The Friars of the Sack in Valencia, "Speculum", XXXVI (1961), pp. 435-438, was incorporated into my The Crusader Kingdom of Valencia, 2 vols. (Cambridge, Mass., Harvard University Press, 1967), I, ch.Il, part 4. See also my The Friars of the Sack in Puigcerdá: A Lost Chapter of 13th-Century Religious History, "Anuario de Estudios Medievales", XVIII (1988), pp. 217-227. The notice and bibliography on the Sacks in the Crown of Aragon, by A. Linage Conde and A. Oliver, in Ricardo García Villoslada ed., Historia de la iglesia en 
Templars, Augustinians, Dominicans, Servites and other orders snatched up their buildings and churches. The friars themselves passed rapidly into other religious groups, with a remnant allowed to rattle about in a few dozen empty priories, liquidating residual assets, forbidden to preach, and eking out a shadow life. Today only a single manuscript of their Augustinian-type rule survives (at the British Museum). Added to a few papal letters and some asides by the chronicler Salimbene of Parma, an acquaintance of the founder, this provides information on their lifestyle, ideals, striped habit, administrative structure, studies (including law and history), chapters general, preaching, and begging. Their basic bibliography, however, can almost be counted on the fingers of both hands.

Further traces do exist, lost in the interstices of alien documentation. Three genres of archival manuscript are particularly promising. A multiplicity of last testaments filed away in secular and ecclesiastical archives carries along symbiotically information beyond that on which the filing legatees focused. Secondly, property notices or transfers after the order's dissolution, which lodged with the papacy or a supervisory bishop or the records of the acquiring corporation, can expose the fully developed local house. Notarial codices comprise a third class of promising materials, though their jumbled nature demands of the researcher the patient stamina of a saint. As with gold-panning or archeological digging, minuscule return must suffice from all three categories. Mere discovery of another priory in the network (and there may be many more) counts as a victory. Fragments can reveal such data as existence of a house or church, its site, foundation and terminal date, improvements, value, personnel, relative popularity (evidenced in wills), library, relations with diocese or with other orders, its patrons and class of

España, 5 vols. (Madrid, Biblioteca de Autores Cristianos, 1979), II, part 2, pp. 123, 151-152, are drawn from my materials. In the inclusive bibliography of my "DIP" article, R.W. Emery's pioneering three articles are still foundational; G. Giacomazzi's two articles, respectively on the Sacks and an edition of their rule, were combined without revision as a small book or offprint (1962); and regional articles have come especially from J. Asen (Cologne), A. Amargier (Provence), H.F. Chettle and A.G. Little (England), K. Elm (Germany, Netherlands), Lluís Feliu (Barcelona), M. de Fontette (Occitania), D. M. Montagna (Perugia), L. Simon (Palma de Mallorca), and E. Ypma (Paris); see also A.G. Rigg's letter from the Sack superior-general there. On the Sack's Santa Ana connection, see Nikolas Jaspert below in note 23. A provisional version of this present study was delivered as an invitational address at the University of Toronto in Canada. 
supporters, and incidental business or a revealing episode. Armed with these clues, the search can widen.

Despite a lush overgrowth of legends and bad history, the bare facts of the order's origins do survive. Its founder was Raimond Athenulf, a member of the cultivated upper middle class (milites, litterati) at the small seacoast town of Hyères in Provence. Briefly a novice in the new Franciscan order until sent away for ill health, he married and had at least one child. Reverting later to his obsession with apostolic beggary, he began recruiting his own brotherhood at Hyères. With a rule based on the Dominican, he established over a dozen houses in the Occitan regions (the later Southern France) by 1251 . In that year he held a chapter general at Marseilles, which petitioned Rome for formal recognition. Innocent IV promptly complied that year, and in 1255 also conveyed the preaching office to all Sack friars trained in university theology. Athenulf himself, more retiring than Saints Dominic or Francis, became only viceprior at the university town of Montpellier. The Franciscan eyewitness Salimbene testifies that the populace received them warmly, so that the order flourished. Their chapter general at Paris in 1258 shows the original Occitan province, plus one for Francia (now northern France), one for England, and one for Spain.

Within Spain their concentration lay, not in the Castilian hinterlands but in the forward-looking mercantile communities of Mediterranean Spain. This was a congeries of kingdoms, counties and regions known as the realms of Aragon, essentially Aragon, Catalonia, the crusader kingdoms of Valencia and the Balearic islands, and districts of Occitania. Over it all presided the count-king James the Conqueror.

From Marseilles, which had just slipped from Arago-Catalonia's overlordship into Capetian hands in the late 1240s, the Sacks spread to every corner of King James's realms. Their first such house, among the earliest for the whole order, was at Montpellier before 1251. The second in James's realms came at Barcelona, between 1252 and 1257. By 1261 the friars had ensconced themselves at his newly conquered Valencia on the Christian-Muslim frontier. They sought the centers of power: Montpellier as James's preeminent Occitan city now that Marseilles was gone; Barcelona the comital capital and favorite city of the king; Zaragoza the capital city of Aragon proper; Lérida the working capital for the realms; Palma de Majorca the capital city of the Balearics; Perpignan the capital of the Roussillon province; Puigcerdá the Pyrenean capital of Cerdagne; and lesser administrative centers like Calatayud and Teruel in Aragon, Perelada and Gerona in 
Catalonia, and Játiva in Valencia. I have already published descriptions of the Sack establishments at Valencia and Puigcerdá. Now Barcelona particularly invites attention, as Catalonia's traditional capital, home of the count-king's major palace, and main port and city of the Realms.

Unlike the other Sack houses, the Barcelona priory has left behind a folder of parchments, by inclusion in the archives of the successors to their property, the Augustinian canons of Santa Ana. Many wills also survive, filed by the cathedral chapter for their almshouse but containing notice also of the Sacks. The wills alone provide material for two or three studies. In our brief and partial survey, we shall exploit only the Santa Ana collection, therefore, and only its high points ${ }^{2}$. By an irony of history our largest view of these poor Mendicants comes from their financial records; we shall concentrate on them. Property acquisitions allow us to locate their convent exactly, for example, and to follow the material evolution of their church.

The new order took up residence at the southwest corner of the city, a brief walk from its western or inland edge. Barcelona in mid-thirteenth century formed a square, framed at the right by the Mediterranean and along the bottom or southern side by a gully or rivulet and its sandy bank. The riverbank in modern Barcelona has become the Ramblas, a giant walkway from the port inland, clear to the monumental Plaça de Catalunya. That plaza was mere countryside when the Sacks arrived, separated from the city by a fortified gate. Just inside that Santa Ana gate, on the inland or western edge of the city, the Plaça de Santa Anna (today the Avinguda del Portal de l'Ângel) funneled visitors to the central cathedral. The Santa Ana space would become in the fifteenth century a showplace for jousts and tournaments, and in our own day a shopping mall. In the 1250s the Sacks settled

\footnotetext{
${ }^{2}$ The Arxiu Diocesà de Barcelona holds in deposit the Arxiu de Santa Anna as carpeta 8 , pergs. 1-259, in which a folder containing pergs. 1-20 is titled "Frares de la Penitència, segle XIII". Before being scattered and diminished by the last civil war, the Sacks collection was in the Fons Santa Eulàlia del Camp, in the Museu Diocesà, and so Lluís Feliu cites them in his El monestir de frares de la Penitència de Jesucrist de Barcelona (1260-1293), "Analecta Sacra Tarraconensia", X (1934), pp. 45-59.
} 
along its upper or northern side, where today Condal street enters it at a right angle ${ }^{3}$.

They were in possession by at least 1261 and acquiring nearby properties. In April of that year, for example, Bartomeu Romeu and his wife Guillamet sold them "all our houses, with gardens, floors, and overhangs, rentals, rights, and jurisdictions, " which lay "in the suburb of Barcelona city beyond the [public] Garrover oven among the old arches"4. Full dominion of this property and of another held by Guillem de Nagera came in November 1262, when the canon and cathedral preceptor Berenguer d'Espiells turned over his seignorial rights, speaking of the monastery [which] has now been begun there" ${ }^{5}$. La Garrofera is a toponym in several Catalan and Valencia places; originally these would seem to have held carob trees or have processed carob beans. Garrover/Garrofé is also a Catalan surname, with the same etymology.

The friars already employed a financial agent by 1262 , the layman Pere de Copons - his role formalized in 1264 as "procurator, agent, syndic, and manager"6. Next year the friars bought from Bernat and Ricomana Marquès another set of "buildings with shops and foundations and constructions and a garden with trees; this adjoined yet another purchase from Pere Reglar "at the west of your monastery"7. In 1264 Berenguera Carbonell and her husband sold them houses with a "garden with trees of various kinds"

\footnotetext{
${ }^{3}$ Agustí DuRAn I SANPERE, Barcelona $i$ la seva història, 3 vols. (Barcelona, Curial, 1973-1975), I, pp. 526, 544 touches on the Sack site, not without incidental error about their history.

${ }^{4}$ Arxiu Diocesà, Santa Anna: Frares, doc. 1 (11 April 1261): "omnes ipsos domos meas cum ortis, solis, et suprapositis, censualibus, iuribus, et dominationibus suis ... in suburbio civitatis Barchinone supra furnum de Garroverio apud archus antiquos".

${ }^{5}$ Feliu transcribes this, "Monestir", doc. 2 (23 November 1262) but misdates it as 1269: "ibi monasterium ubi modo inceptum est", bounded on the west "in via qua itur ad Sanctam Annam". The grant is "illas domos cum platea ... in burgo Barchinone prope furnum qui dicitur de Garroveri".

${ }^{6}$ Arxiu Diocesà, S. Anna: Frrares, doe. 6 (5 May 1264): "procuratorem, auctorem, sindicum, et iconomum." We see Copons active as early as doc. 2 (20 November 1262).

${ }^{7}$ Arxiu Diocesà, ibid., doc 5 (25 April 1263): "ego Bernardus Marchesii et uxor mea Ricomana [vendimus] omnes illas domos nostras cum operatoriis et solis et suprapositis et orto cum arboribus et pertinenciis". Boundaries included: "ab oriente in carraria, a meridie in domibus que fuerunt Petri Regularii alodio vestre domus, ab occidente in vestro monasterio".
} 
that were "contiguous to the church and buildings"8. Their properties in hand and their church up, the community suffered a lawsuit by a citizen, settled out of court in $1267^{9}$. In all this the friars paid large sums in cash $-1,000$ sous for example, and 800 . Much of this a wealthy local novice Berenguer d'Ape brought in with him: "from your patrimony" of 6,000 melgorian sous and 1,500 Barcelona sous. "We expended this entire sum in buying our buildings at Barcelona", including "purchase also of the bell for our church"10. 1267 also saw an audit by Copons - "once, twice, thrice, and more times" in rechecking ${ }^{11}$. Copons himself loaned the busy friars 3,525 sous (about a knight's income for ten years), contracted to be recovered from all gifts below 20 sous each- "the totality of what will be left as legacies or given to our house in any way"12. Copons also went surety for their other current loans $-1,000$ sous, 50 morabatins (some 300 sous), 230 morabatins (some 1400 sous) ${ }^{13}$. At the time of a second audit in

\footnotetext{
${ }^{8}$ Arxiu Diocesà, ibid., doc. 7 (24 April 1264): "ego Berengaria Carbonella uxor Vitalis de Manso ... ad opus domus quam dicti fratres habent in civitate Barchinone et eisdem fratribus perpetuo: ipsas domos nostras cum solis et suprapositis et orto eisdem contiguo cum arboribus diversorum generum et pertinenciis suis, quas habemus ... sub dominio et alodio domus dictorum fratrum in Barchinona, et sunt contigue ecclesie et domibus dictorum fratrum, et terminantur ab oriente, occidente, et circio in domibus vestris et dictorum fratrum".

${ }^{9}$ Arxiu Diocesà, ibid., doc 3 (17 December 1262) was a waiver of prosecution against the order from any lawsuit or complaint, issued by Pere Esquerit.

${ }^{10}$ Arxiu Diocesà, ibid., doc 18 (26 January [1275] 1276): "recepimus de bonis patrimonii vestri ex una parte sex milia solidorum malgurensium et ex alia parte mille quingentos solidos ... [quam] summam persolvimus in empcionem domorum nostrarum Barchinone, scilicet tam in empcionem alodii quam feudi in opere ipsarum domorum, et in empcionem eciam campane ecclesie nostre." The double date comes from Catalonia's Florentine Incarnational calendar, followed from 1180 to 1350; the stated year 1275 is our 1276 .

"Arxiu Diocesà, ibid., doc 8 (9 August 1267): "venistis ad rectum et regale compotum cum Fratre Arnaldo de Crexello ... super omnibus quantitatibus pecunie et rebus aliis quas nomine dicti ordinis recepistis ab aliquibus personis, et super omnibus solucionibus et expensis". This confirmed the actual document drawn on 19 May 1267 (doc. 10): "facto ipso computo bene et legaliter semel, secundo, tercio, et pluries", including a loan by Copons which "expendistis in bonum et utilitatem nostram scilicet in empcionem bonorum in quibus construcximus domum et ecclesiam nostram".

12Ibid. (doc. 10): "in solutum habeatis et accipiatis totum illud quod domui nostre Barchinone legabitur vel dabitur aliquo modo quod excedat summam XX solidorum, tam diu quousque sitis bene paccati vos et vestri". The sum or loan was stated as "de vestra propria pecunia CLXXV libra et V solidos et IIII denarios et obolum" of current Barcelona money. Cf. the same mode of recovering a loan above in doc. 8 (see note 11).
}

${ }^{13}$ Ibid. (doc. 10): "in mille solidis et ... in L morabatinis et ... in CCCXXX morabatinis". 
1270 , the Copons debt had been reduced by a third, which argues strong support at the level of affluent donors ${ }^{14}$.

With suppression of the new order only a year away, the Barcelona house continued to buy adjacent property, pre-paying the full sum of 1,600 sous to a dyemaster and his wife ${ }^{15}$. The purchases as a whole show the Sacks determined to have immediately a proper church and priory as base. They live on alms, which are accruing regularly, and do not acquire investment properties. They are well advised in real estate and loan procedures, are good money managers, and make no move without properly legal contracts. The support indicates in turn that they are visibly attending to those services and sermons and spiritual counseling which were making Mendicants popular with the merchant class all around the western Mediterranean. By summer 1262 no less than ten friars operated out of this center; and the property documents contain the names of fifty-one Barcelona friars during the two decades there. The number and turnover of personnel indicate that this motherhouse prepared the pioneers who then issued forth to found or staff the other houses in James's realms. Though friars who signed only one document may have lived some years at this priory, only six names appear regularly over any span of years.

\section{III}

Fascinating sidelights emerge. The rector, provincial, and prior had their separate seals, which they placed on many charters, none of which can be found today. Copons refers to these "instruments" he holds, each "sealed with their seals." On another occasion Arnau de Creixell notes "a document

\footnotetext{
${ }^{14}$ Arxiu Diocesà, ibid., doc 14 (15 December 1270): "super omnibus debitis que domus vestra Barchinone et domus vestra Terrachone et ordo vester mihi debuerunt usque in hunc presentem diem, ex cause mutui et ex cause fideiussionum et quolibet alio modo". Copons here is an agent also for the Tarragona Sack friary. The Barcelona debts have been consolidated or rather undertaken through the credit of Copons.

${ }^{15}$ Arxiu Diocesà, ibid., doc 17 (12 April 1273): "Arnaldus de Pedros tinturarius et Benencasia uxor eius confitemur ... quod habuimus et recepimus illos mille et sexcentos solidos ... pro quibus vobis vendimus quasdam domos .... in suburbio Barchinone contiguas domibus vestris in carraria que dicitur Sancte Ane prout in instrumento inde confecto ... continetur".
} 
sealed with the seal of our priory". Sigillographers may one day uncover an exemplar, out of the hundreds once available ${ }^{16}$.

One valuable record shows us the priory library. The friars as licensed "academic" preachers had to expand and deepen their university training by continuing study. Happily, we have a partial list of expensive books in their collection by 1271 , at which date they were added to the collateral for the ongoing debt to Copons. This document is at present displaced and perhaps lost; but Feliu copied the pertinent section before the winds of modern civil war swirled the collection apart. It noted that "all the books are in a kind of chest".

They included a Bible "in a huge volume"; four volumes of Peter Lombard on the Sentences; "the writings of Friar Thomas [Aquinas, then still living] in four volumes on the Sentences"; the commentaries on John's gospel by Hugh (of St. Victor?); "a summa on the vices" (perhaps one of the summas then becoming very popular in judging confessional cases, such as that of Thomas de Chobham); the lives of the saints (the Golden Legend?); a book of "Sentences"; "many questions of various masters of theology in one volume"; St. Augustine's Confessions; a book "of exposition of prologues on the Bible"; "three volumes of sermons" (very practical for any Mendicant); St. Remi (of Rheims) on the Apocalypse; a work on the Psalter; "the commentaries of Friar William on Matthew"; books on natural philosophy bound together; a metaphysical summa and "a book on the soul", bound as one; an incomplete volume on natural philosophy; two volumes in verse and prose on an illegible subject; a volume of the "divinations of Huguccio" (probably the great decretist, Huguccio of Pisa); the decretals "with apparatus"; and "the sermons of the Tusculan master"." This was probably not the whole library, nor did it cover other categories of codices the priory must have had, such as service books and house records. All this constituted a practical library for the working preacher, heavy on the modern theologians and on the Bible, with an appropriate dash of philosophy and

\footnotetext{
${ }^{16}$ See for example doc. 10 above in note 11 (1267) "secundum quod continetur in quodam instrumento sigillo nostri prioris sigillato" (the prior for Spain, to Copons). And doe. 14 (16 December 1270): "cum eorum sigillis sigillata", Copons referring to the respective seals of rector, provincial, and prior.
} 
canon law, a few volumes of sermons, a set of the saints' lives for exempla in the pulpit, and for light reading the Confessions ${ }^{17}$.

A corody also turns up among the Barcelona records: a widowed mother was placed by her family in the custody of the friars and at their expense, as a kind of annuity. Upon her death the friars were to receive the total sum deposited. The brothers Bernat and Pere Vilella had made this contractual arrangement with the friars for the support of their mother Joana. The details of the arrangement were drawn in a double charter, divided along the usual intervening letters A-B-C so that both Joana and the friars had separate copies, whose validity could be checked by rejoining them at the cut. With Joana now deceased, the two sons were acknowledging "to you Pere de Copons the procurator and administrator of the house of the Friars of Penitence of Jesus Christ in Barcelona that I am well content and paid up by you, entirely and fully". Joana is the only Sack corodian surviving in the meager documentation; but in light of the universality of that practice, she doubtless represents a category of Sack supporters ${ }^{18}$.

\section{IV}

The pastoral work of the friars, and a poignant tale of a Barcelona couple, occupy one of the surviving local documents. This turns out to be the most important of the Barcelona series, since it introduces a connection between the friars and the celebrated Ramon de Penyafort, constituting indeed a contribution to the diplomatarium of Penyafort. The story or case involved Guillem de Soler from Santa Eugènia de Relat, an inconsiderable village and parish of the Vich diocese north of Avinyó, in a district northeast of Barcelona. He had married Ermessenda de Cases from the even smaller town and parish of Sant Marçal de Relat nearby. They had moved to

\footnotetext{
${ }^{17}$ The original list was lost or displaced, during the civil war; a partial copy had been made in FELIU, Monestir de Barcelona, pp. 3-4.

${ }^{18}$ Arxiu Diocesà, ibid., doc 11 (18 February [1267] 1268): "recognosco tibi Petro de Coponibus procurator) et aministratori domus fratrum Penitencie Ihesu Christi in Barchinona et tuis quod sum bene paccatus ... super hiis omnibus que tu tenebaris dare Iohanne quondam matri mee racione alimentorum suorum et super omnibus questionibus, et reddo tibi de presenti instrumentum divisum per alphebetum inter te et me et dictam matrem meam. " Here the mother had died and the contract is being resolved. The expenses for the mother appear in Copons' audit in doe. 10 (above in note 11): "et matri dicti Bernardi Vilela in prestandis sibi alimentis quam diu vixerit, que nos ei prestare tenemur." On the double date here, see note 10.
} 
Barcelona, bringing with them a domestic problem. They had never consummated their marriage, apparently because of a romantic interlude between Ermessenda and Guillem's brother Ramon before entering it. Strangers in the metropolis, they took their problem before the diocesan Official Pere de Perers, the usual judicial delegate of the bishop, "attesting that the marriage had been illicit" and putting in motion a judicial appeal "that a divorce be solemnly published, and that we be separated from one another". Too busy to cope, the Official delegated the case to Guillem de Canet, rector of Sant Jaume in Barcelona, "that he might investigate it and conclude it according to the process of the law".

Canet "industriously" began his inquiries. During their individual confessions beforehand, "I the said Ermissenda, in the forum of the soul" and under the seal of confession, explained that "I had carnally known Ramon de Soler, formerly the brother of the said Guillem de Soler, likewise joining myself to him". Canet's sentence declared the marriage valid though unconsummated, since he could not sufficiently establish the previous liaison from one participant's secret confession. "Seeking a better opinion" they betook themselves to Friar Pere d'Albareda "of the order of the Friars of Penitence". The year was 1270 , with the friars installed in their new church and priory. Had the couple turned to them as relative outsiders, learned in the university theologies? Having ascertained the facts in confession, Albareda knew precisely what to do with such a lost cause. "He turned us over to Friar Ramon de Penyafort, the physician of souls".

Penyafort was a towering figure in contemporary Europe, the legal genius of his age and active on every religious front. He had left the castle of Penyafort long ago for an ecclesiastical career at Barcelona's cathedral, later taking his law doctorate at the University of Bologna and holding a chair there for five years, a distinction he abandoned to join the new Dominican Mendicants. A pioneer in moral philosophy, he also soon included among his writings the monumental Decretals, basic to universal canon law down to the present day. He helped revise the Dominican rule, so important to the Sacks' own constitutions, and helped organize the rule which stabilized and really began the Mercedarian order; it seems appropriate that he would have been consulted by, and ardently interested in, the Sacks. He had turned down the Tarragona archbishopric but could not escape becoming third general of the Dominicans. Freed from that, Penyafort operated out of Barcelona, involved in the life of his friend King James and in governmental affairs, establishing schools of Arabic and 
Hebrew throughout the realms in a sweeping effort at conversion, and causing Thomas Aquinas to compose his masterwork the Contra gentiles for the same purpose. At the time of our story, Penyafort was a vigorous 85 years of age; upon his death at 90, King James's bishops would demand his canonization, an honor which would be delayed three hundred years. It is a measure of the popular esteem for Penyafort that our couple refers to him so affectionately in this legal statement as their "medicum animarum".

Weighing "each and every detail", seeing "the tearful eyes" of the young couple, testing one confession against the other, and noting that no ill will existed between the two, Ramon gave sentence in his special capacity of papal judge that divorce should be proclaimed "in the said illicit marriage" and that the two should separate forever. A last stage of the proceedings found Guillem and Ermissenda signing their acceptance of the decision, with Guillem returning "some small sum of money" which had been the dowry. Besides three friends as witnesses, the only other person on hand was the Sack friar Pere d'Albareda. Penyafort had delegated him to act as official supervisor to these proceedings. Albareda's role had thus been more than that of a facilitator. Penyafort had kept him abreast of the proceedings, and had "licensed and ordered" him to assume the central role in the closing ceremonies ${ }^{19}$.

\section{V}

The connections of King James with the Sacks of Barcelona are of particular interest. He did not cultivate them so obviously as he did the Franciscans and Dominicans, whose churches were often the itinerant king's place of business and who provided prelates and important clerics to his

\footnotetext{
${ }^{19}$ Arxiu Diocesà, ibid., doc 16 (18 May 1270): "compareremus coram Petro de Pirariis domini barchinonensis episcopi officiali, dicentes et proponentes quod matrimonium illicitum fuerat inter nos contractum, super quo iusta recione querebamus inter nos divorcium celebrari ... Dictus Petrus comisit dictum negocium Guillelmo de Caneto ... Qui Guillelmus de Caneto, auditis nostris confessionibus et diligenter veritate ipsius negocii inquisita ... [the sentence here]. Nos enim melius consilium inquirentes ... cucurrimus ad fratrem Petrum de Albareta de ordine fratrum Penitencie, qui prius audita confessione remisit nos ad fratrem Raimundum de Pennaforti, medicum animarum ... [qui] pronunciavit de lure in dicto illicito matrimonio divorcium celebrari". After the process before Penyafort, they returned to the Sack friar to make a formal dissolution of the marriage before him. The full document will be published separately.
} 
realm. The Sacks had arrived too late, relatively, and had only just built their churches and established an initial popular base, when they had to disappear. The king did give them alms and property. An episode of 1264, hidden away in the king's registers until now, reveals a closer relation than has hitherto been evident. In November of that year King James acknowledged that "you Arnau Llober, of the order of Penitence of Jesus Christ", have loaned the crown 400 golden doubles or nearly 5,000 Barcelona sous. The king has repaid a hundred of this but still owed 296 golden doubles (doblas del amir) or some 3,500 Barcelona sous. James was then at war again with the Muslims, this time to help his son-in-law, King Alfonso el Sabio of Castile; the bishop of Barcelona had supplied a warship of his own for the occasion. The Sack loan was not for that aggressive enterprise, surprisingly, but to support a diplomatic mission into Islamic North Africa, "when we sent the noble Garcia Ortiz [de Azagra] into Tunis".

The extraordinary interest yielded by crown proto-bonds in such crises explains why the Sacks had responded so generously. The same interest, and the rapid retirement of such bonds as soon as the authorities could catch their collective breath and substitute bonds with normal interest, explains why the king had already repaid over a fourth of the amount and was keeping close tab. What is less easy to explain is how the friars had so large a fund so early, liquid enough to release at this opportunity. Unless they had amassed it from local benefactors during the years immediately preceding, one answer is that this also was from the patrimony of the friar-become-knight, Berenguer d'Ape, whom we have already met. Analysis of the dates shows they could easily have wrested the money from the reluctant executor by 1263 . The sum itself was large enough to allow continued purchase of properties; and rapid repayment by the crown could have dumped it back into the building fund by 1265 or 1266 .

King James assigned recovery of the remaining 296 doubles or some 3,500 Barcelona sous, "to have and receive from the moneys which we ought to have from the people of Catalonia now, by reason of [their] subsidy". The "now" and "subsidy" suggest a crisis or war levy, which emergency loans such as ours had anticipated. James ordered "the collectors of the said subsidy, that they are to give and pay you the aforesaid doubles, from the first moneys which they receive from it". They are then "to recover from you this debt bond, and the other debt bond which you have from us for the said four hundred doubles". In the original bond Bonanat Cabot had stood surety for crown repayment. Economic advantage alone might explain 
this whole transaction; but medieval men, cleric and lay, seldom disentangled and purified their motives so inhumanly. In the crisis atmosphere, with limited war afoot on one flank and the whole southern frontier plunged into war on the other, with the city fathers outfitting a war fleet and the bishop arranging a separate warship and campaign, and with crusade already in the air (though Pope Alexander would not formally declare it until 1265), the Friars of the Sack must have shared the general enthusiasm. And in a society where Mendicants and king had an unusually close relationship, the newcomers would have been aware that their timely contribution could gain the king's attention and good will ${ }^{20}$.

At the end of King James's life, in 1274 when he had but a year to live, a grand assembly representing all Christendom gathered in the city of Lyons in France, at the head of navigation on the Rhone River, for the fourteenth ecumenical council. It could not dazzle like its predecessor, Innocent III's Fourth Lateran sixty years before, when King James was a boy; but it was impressive in its own right. The thousand delegates included 250 bishops, ambassadors from Angevin Italy, England, France and Germany, a special contingent from the Byzantine emperor to discuss crusade and church reunion, and even an embassy from the Mongols (two would be baptized during the council). King James was a guest of honor, an experience so thrilling to the old sinner that he devoted to it nineteen chapters of his autobiography. (Pope Gregory sat James at his right "so very close, that no one could fit between me and him", and on a chair only a few inches lower, and he let the king keep his hat on) ${ }^{21}$. James had even brought a gold crown along, for a solemn coronation, but he balked at the papal fee and went home uncrowned. Behind the pageantry, the Mendicant orders fought for their corporate lives; on the last day of that long hot summer, all but four were swept away. The Friars of the Sack were the most

\footnotetext{
${ }^{20}$ Arxiu de la Corona d'Aragó, Cancelleria, James I, Reg. Canc. 14, fol. 67 (12 November 1264): "vobis fratri Arnaldo Loberi de ordine Penitencie Ihesu Christi ducentas sex duplices mirias que vobis remanent ad solvendum de quadringentis duplicibus miriis quas nobis mutuastis quando nobilem Garciam Ortiz misimus apud Tunicium". The coins here were a Castilian imitation of the gold diner struck by the Murcian emir Ibn Ayad in 1145-1147 (miria is Latin adjectival emir). In 1286 this dupla auri mirie Castelle was worth 12 Barcelona sous.

${ }^{21}$ King James, Llibre dels feyts, in Ferran Soldevila ed., Les quatre grans cròniques (Barcelona, 1971), cap. 528: "molt prop, que null hom ni es pogra metre entre nós e ell, e la sue cadira no era pus alta que la nostra d'una palmada". King James's registers show many connections with the Sacks in his realms, through it is not always possible to locate the specific Barcelona house in these.
} 
promising of these. King James's long narcissistic account takes no note of this episode.

\section{VI}

The suppression at Lyons must have come to Barcelona's friars as a stunning ambush. Its immediate effect however was minimal. Superiors and community here stayed in place. There was brave talk of reversing the decision at Rome. Property and resources had to be kept intact against that day. As late as 1277 the community could muster eight friars to sign a financial document, as good a personnel record as on any previous occasion, and optimistic talk about the order in that document ran high. At least one friar broke ranks at this time, to join an order with more future. As luck would have it, this had been the wealthiest recruit; his sudden request to transfer his patrimony from the sinking ship to the sound one evoked a minor panic.

This Berenguer d'Ape of Barcelona had moved to "the military order of Santiago", a bizarre leap from an apostolate of meek peace to an apostolate of aggressive war, from a setting of humility to the appurtenances of pride. Like all the military orders in Spain, Santiago was still a fighting outfit. Its acceptance of Berenguer tells us something about his social status. His new religious community displayed other differences from his former state. Santiagans could marry, though celibacy was exalted as preferable; Berenguer doubtless kept his previous vows for life, but the families of colleagues formed a backdrop to his new style. More to the point, Santiagans brought their share of the family patrimony, as indeed Berenguer had done when becoming a Sack friar; this they could either surrender to the order or, by a strange arrangement, keep its usufruct personally for life. Berenguer had moved from strictest poverty, both corporate and personal, to an easier and half-secular existence, from rough sacking to knightly armor (alternating with monkish habit), from modern open apostolate to a mix of alternating monastic seclusion and military activity.

Berenguer now sought to transfer his inheritance from the Sacks to Santiago. By this time it had all been spent on Sack buildings and property. Even if they could liquidate, however, the council had decreed that the disposal of all Sack property after the death of each community was to belong to the pope for the Holy Land crusaders. The stage was set for the 
ubiquitous lawyers. To avoid conflict, the Sacks proposed a joint separatebut-equal tenancy of the Sack monastery, with Santiago advantageously positioned to claim it all when the last Sack there died.

A condition of the Santiago merger had been that "we [Sacks] hold and possess the buildings as long as we shall live in the same order of Penitence [the Sacks], with the habit on, namely all as we are or one of us". If the pope were to restore the Sacks, the Santiago knights "are bound to get out of the site and buildings immediately with your entire community"22. Two decades and eight popes later, the last five discouraged Sack friars signed a true merger in 1293, this time with their neighbors the canons of Santa $\mathrm{Ana}^{23}$. Two of these Sacks were still active in 1305, as an episcopal visitation notes ${ }^{24}$. The tale of the Santa Ana merger, however, deserves a separate retelling, as do their relations with Barcelona's notable families as seen in wills. These will form chapters in my comprehensive history of the Sacks in the realms of Aragon.

Religious orders are works of art. They are mobile art forms moreover, diffusing themselves widely, even globally. Their materials are

\footnotetext{
${ }^{22}$ Arxiu Diocesà, ibid., doc 18 (1275-1276: see note 10): "asserendo quod predicta qua[ntitas] pertinebat ad ordinem vestrum milicie Sancti Iacobi, pro eo quod vos predictus Frater Berengarius fecistis sicut licite potuistis transitum de ordine nostro ad ordinem milicie Sancti Iacobi." Santiago could recover the sum, if the pope agreed and if their claim were upheld, "super predictas domos nostras Barchinone [et] campanam ecclesie nostre." But the friars hope for restoration of the Sacks: "si ordo noster in statu suo non fuerit restitutus." Meanwhile, "recepimus vos ut amicos benefactores et hospites ... quamdiu vixeritis in situ nostro de Penitencia" until such a restoration; "salvo tamen et retento nobis expresse quod nos quamdiu vixerimus in dicto ordine de Penitencia cum habitu, omnes scilicet sicut sumus vel unus nostrum, teneamus et possideamus predictas domos, et vos possitis ibi habitare et remanere nobiscum in loco vobis deputato". This arrangement seems to have left no echo in Santiago records, so far as I can discover, and this is useful also for the study of that order.

${ }^{23}$ Feliu transcribes this long contract, "Monestir", doc. 4 (30 July 1293), pp. 56-59. On the Santa Ana priorate of the canons of the Holy Sepulcher and its connection with the Sacks, see Nikolas JASPERT, Stift und Stadt: Das Heiliggrabpriorat von Santa Anna und das Regularkanonikerstift Santa Eulàlia del Camp im mittelalterlichen Barcelona (1145-1423), Berlin, Duncker und Humblot, 1996.

${ }^{24}$ Report edited by Josep BAUCELLS I REIG in his Els monestirs del bisbat de Barcelona durant el pontificat de Ponç de Gualba (1303-1334), "II Col-loqui d'Història del Monaquisme Català", Poblet, Abadia, 1972, pp. 181-187.
} 
human beings, bonded into community patterns of action. They are a performance medium, more dynamic than paint or stone or sound. Though orders assume institutional structures vaguely similar to each other, they vary as dazzlingly as the products of any art. A current encyclopedia of orders has found over four thousand of them in Christian history. The historian may tidy them into categories according to work, rule, spirituality, or behaviors; but the relentless unicity keeps breaking through. In the High Middle Ages, adaption to the needs of Christian society produced such varieties as the military orders, the ransomer orders, the hospital orders, the orders of canons, and of course revivified traditional monasticism in such forms as Cluny, the Cistercians, and the Carthusians. Within each of these general categories, the separate orders differed greatly from each other. Nor did any order remain static over time, but fluidly adjusted to changes and cultures. Within a given order, itself a mass movement and often trailing a lay movement beside it, no single person was entirely absorbed by the structure, but expressed himself or herself as irreducibly unique, within a uniquely contextualized lifespan.

Given such unicity and aesthetic, historians cannot afford to lose this fleeting but not inconsiderable Mendicant brotherhood. Within two short decades, and on the heels of wildfire expansion to the farthest corners of Christendom, the Sacks had legally ceased to exist. The physical order then expired house by house, however, and man by man, winking out like a galaxy of dying stars. The historian can only salvage the astral detritus to restore some semblance of the Sack's vanished glories.

\section{RÉSUMÉ}

De 1251 jusqu'à leur suppression par le Concile de Lyon II en 1274, les nouveaux Ordres Mendiants connurent une impulsion qui envoya les Frères de la Pénitence de JésusChrist, ou Frères Sachets, dans toute l'Europe et plus particulièrement dans le Royaume d'Aragon. Bien que nous ne puissions retracer le réseau de leurs couvents qu'à partir de manuscrits retrouvés ça et là, un dossier de parchemins conservé à l'archi-diocèse de Barcelone nous donne de nombreux détails concernant leur présence dans cette ville. Il y est fait état notamment du contenu de leur bibliothèque, de leur conseil pastoral canonique, de leur nouvelle église et de leur couvent, des 51 frères qui y ont séjourné, de leurs gestionnaires laïques, de leurs procès, de leurs prêts importants au roi Jacques et de leurs opérations fiscales lucratives. 


\section{SUMMARY}

Enthusiasm for the new Mendicant movement spread the Brothers of Penitence of Jesus Christ, or "Sack Brothers", all over Europe and specially in the realms of Crown of Aragon, from 1251 to their suppression by the Council of Lyons II in 1274. Though we can reconstruct their network of convents only from randomly surviving manuscripts, a folder of parchments at Barcelona's Arxiu Diocesà enables us to explore their Barcelona experience in some detail. This includes the content of their library, their pastoral-canonical counseling, their new church and convent, the 51 friars who passed through here, their lay moneymanagers, their lawsuits, their large loans to King James, and their prosperous fiscal maneuvers. 